\title{
Analysis of the internal shading in a photovoltaic greenhouse tunnel
}

\author{
Alvaro Marucci, Danilo Monarca, Andrea Colantoni, Enio Campiglia, Andrea Cappuccini \\ Department of Agriculture and Forest Sciences, University of Tuscia, Viterbo, Italy
}

\begin{abstract}
In recent years, the increasing interest in energy production from renewable energy sources has led to photovoltaic elements being placed on greenhouse coverings. The shading of crops by these elements can, however, cause problems regarding the normal course of agricultural activity. All studies thus far on the application of photovoltaic (PV) panels as a greenhouse covering material have focused on flat roof structures. Tunnel greenhouses, due to their curved shape, do not lend themselves easily to accommodating PV panels on even part of the cover. In this study, we analysed the shading variation inside a tunnel greenhouse that was produced by applying flexible and transparent PV panels in a checkerboard arrangement. The transparent flexible PV panels are manufactured using monocrystalline silicon cells, with an efficiency of $18 \%$, incorporated into polymers with high resistance. The PV panel dimensions are $1.116 \times 0.165 \mathrm{~m}$. The simulation software Autodesk ${ }^{\circledR}$ Autocad $2010 \AA$ was used for this study. The variation and distribution of the shading percentage of PV panels were analysed in relation to the surface area affected by the photovoltaic roof, the total area of the greenhouse and the section of the greenhouse. In particular, we studied the variations in the percentage of shading and the size of the shaded area on the twenty-first day of each month of the year. The results show some regularity in the shading percentage, mainly due to the curvilinear shape of the section of the greenhouse. From mid-March to midSeptember, the shading in the middle of the day is almost always
\end{abstract}

Correspondence: Alvaro Marucci, Department of Agriculture and Forest Sciences (DAFNE), University of Tuscia, Viterbo, Italy.

Tel.: +39.0761.357365 - Fax: +39.0761.357453.

E-mail: marucci@unitus.it

Key words: Photovoltaic greenhouse; renewable energy; shading; semitransparent flexible photovoltaic panels.

Contributions: the photovoltaic greenhouse tunnel was conceived and realized by Prof. A. Marucci and Dr. A. Cappuccini. The authors contributed to this work according to their areas of expertise.

Received for publication: 28 October 2016.

Accepted for publication: 15 April 2017.

(C) Copyright A. Marucci et al., 2017

Licensee PAGEPress, Italy

Journal of Agricultural Engineering 2017; XLVIII:622

doi:10.4081/jae.2017.622

This article is distributed under the terms of the Creative Commons Attribution Noncommercial License (by-nc 4.0) which permits any noncommercial use, distribution, and reproduction in any medium, provided the original author(s) and source are credited. inside the greenhouse. In the other months of the year, it is partly inside and partly outside the tunnel greenhouse. With the photovoltaic arrangement adopted, the percentage of shading during the year never exceeds $40 \%$.

\section{Introduction}

In recent years, the interest in energy production from renewable sources, which is also subject to considerable economic incentives, has allowed photovoltaic elements to be placed on the covers of agricultural buildings, such as livestock, storage and processing warehouses for agricultural products and for agricultural tools. Also the structures for crop production (greenhouses) could not escape this trend.

Thus, greenhouses that had roofs that were partially covered with photovoltaic elements and that occasionally had such elements on the sides were built to produce energy from renewable sources and at the same time grow plants. These structures are widely used in the production of crops with low energy requirements, such as mushrooms, and for specialized functions as insect farming.

Transforming the solar radiation surplus into electrical energy is of extreme interest due to its double benefit: it solves the problem of excess solar radiation in the greenhouse and produces electricity from renewable sources without negative environmental effects.

This solar radiation surplus is considerable, especially in hot climate areas, where it can reach $50 \%$ of the incident radiation under the best conditions (12:00, clear day, June).

In fact, in these areas, the solar radiation exceeds the plants' requirements for much of the year, requiring various methods to cool the internal environment.

In addition to shading the greenhouse (Lorenzo et al., 2003), which can intercept or reflect a significant portion of the incident solar radiation, other methods of controlling the internal air temperature of the greenhouse are used: evaporative pad cooling systems, fog systems, or a combination of both, ventilation systems (mechanical or natural) and sky systems (coverage fully open).

Shading methods can reduce the solar radiation inside the greenhouse and consequently the internal air temperature and relative humidity (Kittas et al., 1999; Soni et al., 2005). Furthermore, this effect saves energy by reducing the cooling load and thus electricity consumption (Al-Helal and Al-Musalam, 2003).

The effect of shading on the crops is a theme that has been discussed at length. It depends primarily on the climatic conditions of the study area and can increase agricultural production (Gent, 2007; Kadowaky et al., 2012).

In Egypt, tomato plants were cultivated in a greenhouse with $30-40 \%$ shade. They had higher yields and more fruit than did the plants grown without shade. Increasing the shade density above $40 \%$ decreased flowering and yield (Abdel-Mawgoud et al., 1996). 
In climates with more moderate temperatures, shade typically reduces yield of tomato grown in a greenhouse. The structure and covering of a greenhouse reduces light intensity, so additional shade could be deleterious (Gent, 2007).

In Brazil, a humid subtropical climate, $52 \%$ shade reduced yield by $20 \%$ (Sandra et al., 2003). In England, a cool and lowlight environment, $23 \%$ shade reduced the yield by $20 \%$ (Cockshull et al., 1992).

In recent years and in regions with high levels of solar radiation, various studies have focused on the possibility of replacing the classic shading nets with photovoltaic (PV) panels. This possibility allows the solar radiation to be used to produce energy from photovoltaic elements instead of being lost with shading nets (Yano et al., 2009, 2010; Kadowaki et al., 2012; Marucci et al., 2012, 2013a, 2013b; Cossu et al., 2014; Yano et al., 2014).

These solutions are all characterized by an inability to vary the shading percentage, which adversely affects the crops. Recently, the dynamic photovoltaic greenhouse concept has been introduced (Marucci et al., 2015; Marucci and Cappuccini, 2016a, 2016b). With this solution, the shading inside the greenhouse is continuously variable because the PV panels can rotate at any moment of the day along the longitudinal axis, and highly reflective aluminum mirrors allow the recovery of the solar radiation that would otherwise be lost by reflection (Marucci and Cappuccini, 2016a, 2016b).

Italian laws assign a threshold value, usually $25-50 \%$ of the projection on the soil, for the roof (Tudisca et al., 2013; Cossu et al., 2014). These ranges, designed to avoid financial speculation (maximizing the government incentive to the detriment of crop production), seem not to be based on scientific results concerning the agricultural performance required from the photovoltaic greenhouse but only on experiential assessments (Castellano et al., 2016).

The spatial distribution of the shades is an important parameter for choosing the best combination of PV panels and crops (AlShamiry et al., 2007; Dupraz et al., 2011; Lopez-Marin et al., 2012; Urena-Sanchez et al., 2012).

Following the above discussion, this paper aims to evaluate the shading variations due to transparent and flexible PV panels installed on the roof of a tunnel greenhouse. The layout of the PV panels was a checkerboard pattern.

All studies on the application of PV panels as a greenhouse covering material have focused on structures with flat roofs, which are better suited to accommodate the classic rigid PV panels. Conversely, tunnel greenhouses are characterized by a curved surface that does not easily accommodate such PV panels. With this research, however, the possibility of using PV panels in tunnel greenhouses has been examined.

In particular, the aim of this work is to evaluate the shading inside a tunnel greenhouse to which flexible and partly transparent PV panels were applied in a checkerboard layout. The software Autodesk ${ }^{\circledR}$ Autocad2010 ${ }^{\circledR}$ was used. For this purpose, we examined the variations in the internal shading degree and the size of the shade during the $21^{\text {st }}$ day of each month of the year.

This research is part of the FOTOAGRI project (technological innovation directed to the design and recovery of greenhouses through the use of PV panels and the development of a new production model for horticulture and floriculture), financed by the Italian Ministry of Agricultural, Food and Forestry Policies (MiPAAF).

\section{Materials and methods}

This shading simulation was carried out on a tunnel greenhouse located at the experimental farm $N$. Lupori of the University of Tuscia in Viterbo (Lazio, Italy, $42^{\circ} 25^{\prime} 38^{\prime}$ N, $12^{\circ} 04 ' 51$ ' E, $306 \mathrm{~m}$ above sea level).

The tunnel greenhouse is constructed of galvanized steel arches with a circular section $(\Phi=100 \mathrm{~mm})$ at intervals of $2.00 \mathrm{~m}$. The end caps are made of fiberglass and have a grid (east) and an extractor (west) to maintain the protected environment through forced ventilation. The tunnel has no openings for natural ventilation.

The covering material is corrugated polycarbonate with fiberglass end caps and the greenhouse tunnel has an EW orientation.

On the cover, the semi-transparent flexible PV panels have been positioned in a checkerboard arrangement, 19 for each string (Figure 1), and the PV panels' position is indicated in Figure 2.

The dimensions of the greenhouse are as follows: i) width: 8 $\mathrm{m}$; ii) length: $30 \mathrm{~m}$; iii) max height: $3.20 \mathrm{~m}$.

The choice of the location of the PV panels on the greenhouse tunnel (Figure 2) was made in such a way that the shadow was projected much as possible inside the greenhouse and the PV panels were much as possible orthogonal to sunlight despite the considerable annual variation of their zenith angle.

The flexible PV panels, with the partially semi-transparent support panel, were made by Solbian srl (Avigliana, Turin) using monocrystalline silicon cells, with a maximum efficiency of $18 \%$, embedded inside a technopolymer with high resistance. The dimensions of the PV panels are $1.116 \times 0.165 \mathrm{~m}$. The PV panels leaning against on the cover are equidistant $(0.165 \mathrm{~m})$ and parallel to each other.

The choice of partially semi-transparent PV panels makes it possible to reduce the shading on the roof of the greenhouse using a partially transparent support panel for the photovoltaic cells. Only photovoltaic cells are completely opaque to solar radiation. The PV panels on the cover of the tunnel greenhouse intercepts the direct solar radiation incident on them. Only a small part of the solar radiation passes through the edges of the semi-transparent support panels in a diffuse form. This energy has been considered negligible in the shading calculation. This research has only the

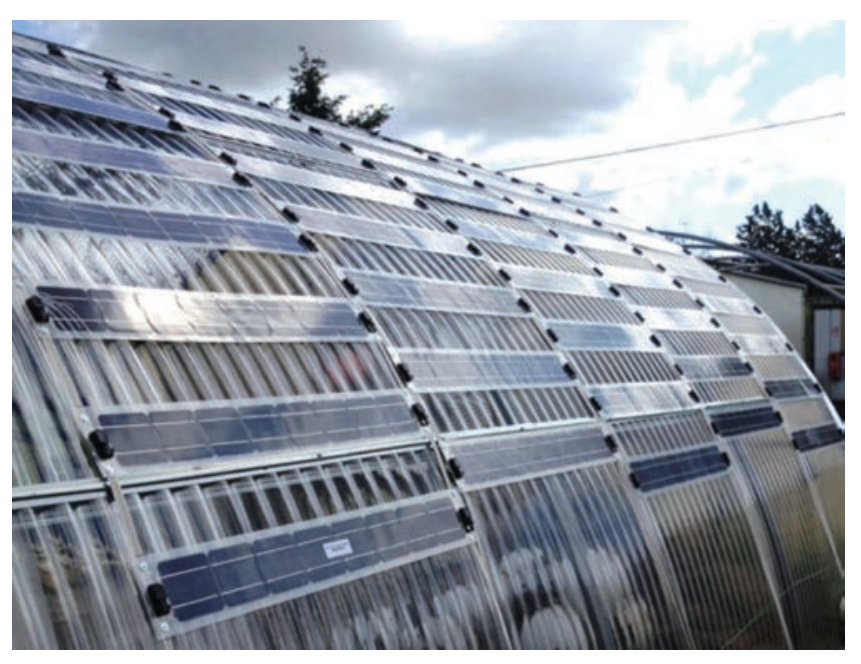

Figure 1. Semitransparent flexible photovoltaic panels in a checkerboard arrangement (south view). 
purpose to evaluate the distribution and uniformity of shading of the PV panels in a greenhouse tunnel according to the scheme proposed, for comparison with the same greenhouse without shading just do not consider the PV panels.

The shading simulation was performed using the Autodesk ${ }^{\circledR}$ Autocad $2010 \AA$ software. The three-dimensional model of the tunnel greenhouse with PV panels was made with Autocad elementary $3 \mathrm{D}$ objects, extruded objects and surfaces of revolution.

Each object has been associated with its material with the corresponding radiometric characteristics (transmittance, reflectance and absorbance) already present in the Autocad software.

The radiometric characteristics vary continuously with the angle of incidence of the sunrays and only affect the transmitted radiation in the part of cover not covered by the PV panels.

Using geographic coordinates the software calculates the instantaneous position of the sun, and later through the rendering simulates the shading of PV panels on the roof and then inside the greenhouse. The variation of the shading percentage and its distribution were analysed in relation to: i) the horizontal surface area affected by the photovoltaic cover; ii) the horizontal total surface area of the greenhouse; and iii) the section of the greenhouse (Figure 3) for to highlight the solar radiation distribution in the cross section. The variations of the shading percentage and the size of the shaded area during the $21^{\text {st }}$ day of each month of the year were studied. These dates were chosen to include the days corresponding to the solstices. All processing related to solar time.

To highlight the changes in the position of the shaded area and evaluate the uniformity of the shading, the distribution of the shadows was studied, examining the area corresponding to the width of a single string of PV panels (surface of the tunnel greenhouse shaded by a row of PV panels) in relation to the width of the greenhouse, with reference to $12: 00 \mathrm{pm}$ of the $21^{\text {st }}$ day of each month.

Additional processing concern the calculation of the shading percentage of the internal surface to the tunnel greenhouse, with reference both to the entire covered area, including the non-shaded portion (greenhouse), and to only the surface shaded by the PV panels (string) (Figures 3 and 4):
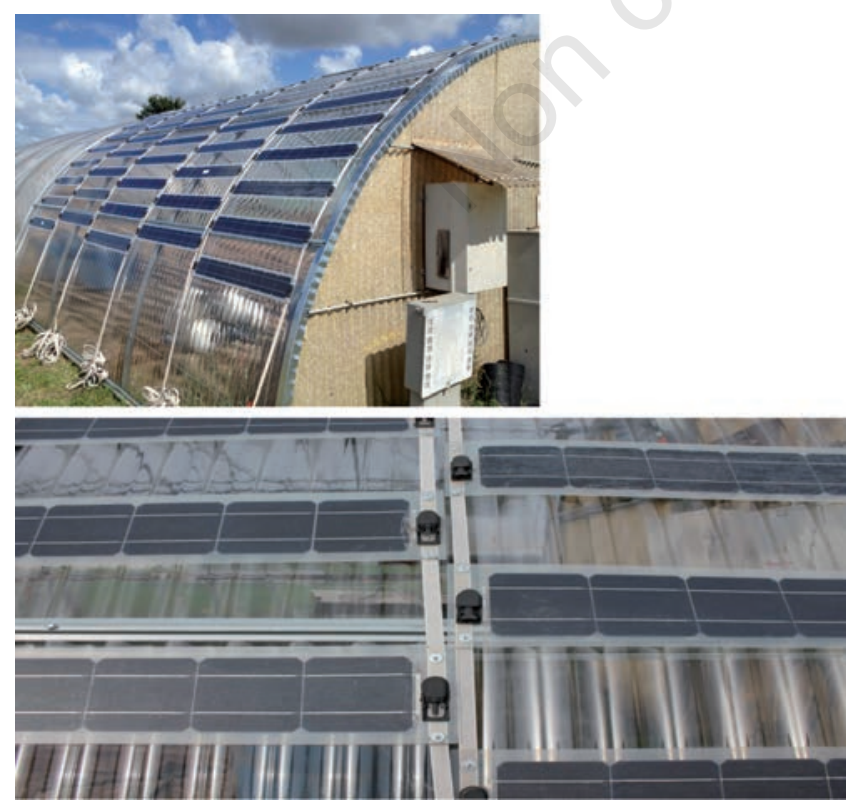

Figure 2. Photovoltaic panels installed on the greenhouse.
$\% S_{g}=\frac{A_{s p}}{A_{g}} 100$

where:

$\% S_{g}=$ percentage of shadow in the total horizontal area of the greenhouse;

$A_{s p}=$ horizontal area shaded by PV panels;

$A_{g}=$ greenhouse horizontal area;

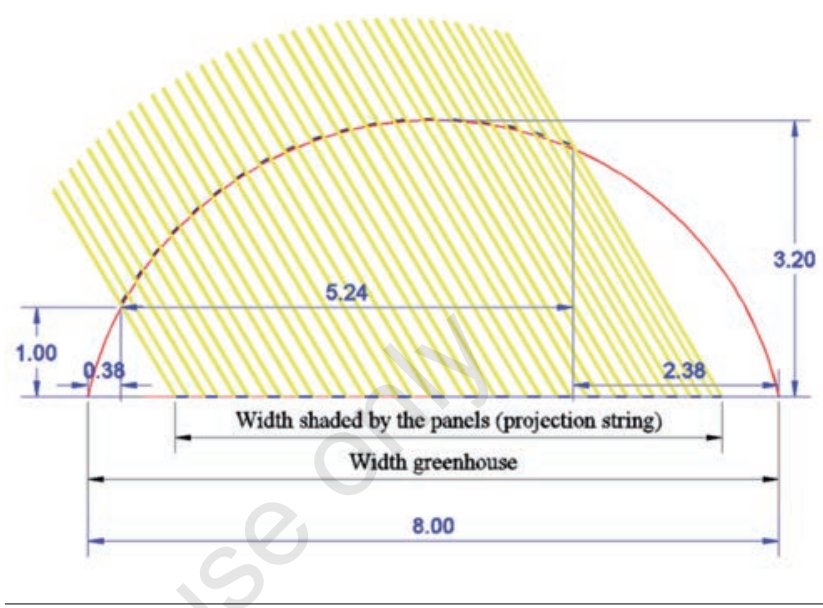

Figure 3. Section of the greenhouse with the photovoltaic panels position and light distribution in the cross section.

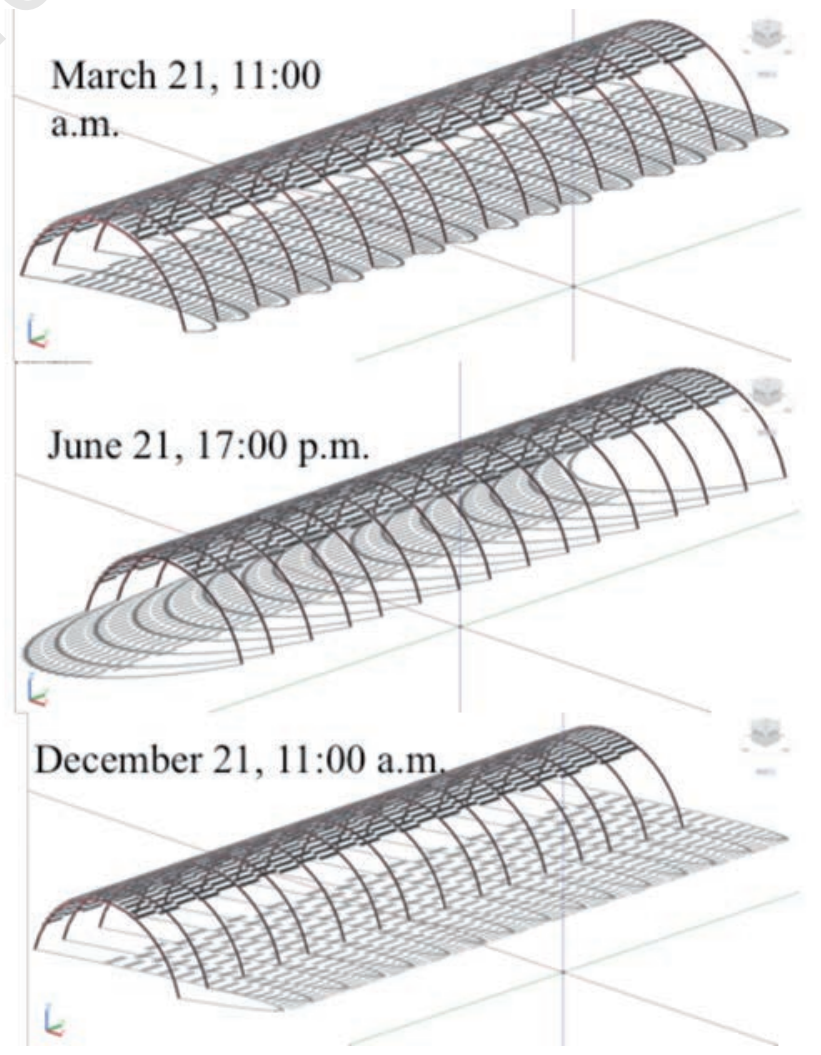

Figure 4. Axonometric projection of the experimental tunnel with the installed photovoltaic panels (North-East view). 
$\% S_{p}=\frac{A_{s p}}{A_{p}} 100$

$\% S_{p}=$ percentage of shadow in the horizontal area under photovoltaic cover (projection string);

$A_{s p}=$ horizontal area shaded by PV panels;

$A_{p}=$ horizontal area under photovoltaic cover (projection string).

\section{Results and discussion}

The Figure 4 shows the distributions of shading by PV panels during some hours (from 9:00 to 12:00) of the twenty-first day of certain months to represent the annual trend.

During the second part of the day, the shadowing presents a symmetrical trend of the morning compared to the value of the 12 O'clock. In the first and last hours of the day, the shadows undergo a substantial longitudinal translation, while the traverse translation is negligible (Figure 4). With the selected arrangement of PV panels on the roof, from mid-March to mid-September, the shading in the middle of the day is almost always inside the greenhouse. During the other months of the year, it is partly inside and partly outside the greenhouse tunnel. The Figure 4 shows that on December 21 , at 11:00 a.m., approximately $50 \%$ of shading is outside the greenhouse.

\section{A) Entire greenhouse surface}

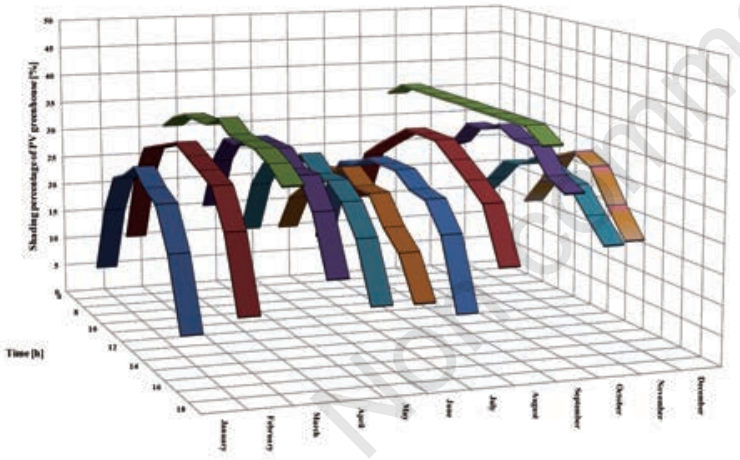

B) String surface

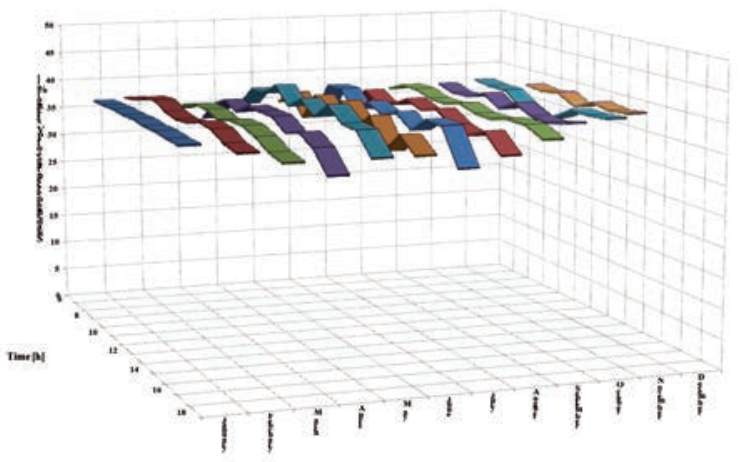

Figure 5. Shading percentage with reference to the string and to the entire surface of the greenhouse.
The Figure 5 shows the values of shading percentage for each hour of the $21^{\text {st }}$ day of March, June, September and December, with reference both to the part shaded by PV panels (string) and the entire horizontal surface of the greenhouse (whole width of the greenhouse, even the not shaded part by the PV panels). In both cases, the width of a string of PV panels $(1.16 \mathrm{~m})$ was considered. The shading percentage of the PV panels under the string is constant for the duration of the day, while the value related to the entire greenhouse surface shows the same constant trend as the value under the string in the vicinity of the equinox (March 21 and September 21). When the considered day is approaching the solstice (21 June and 21 December), the trend of shading percentage with respect to the entire greenhouse surface assumes the trend of
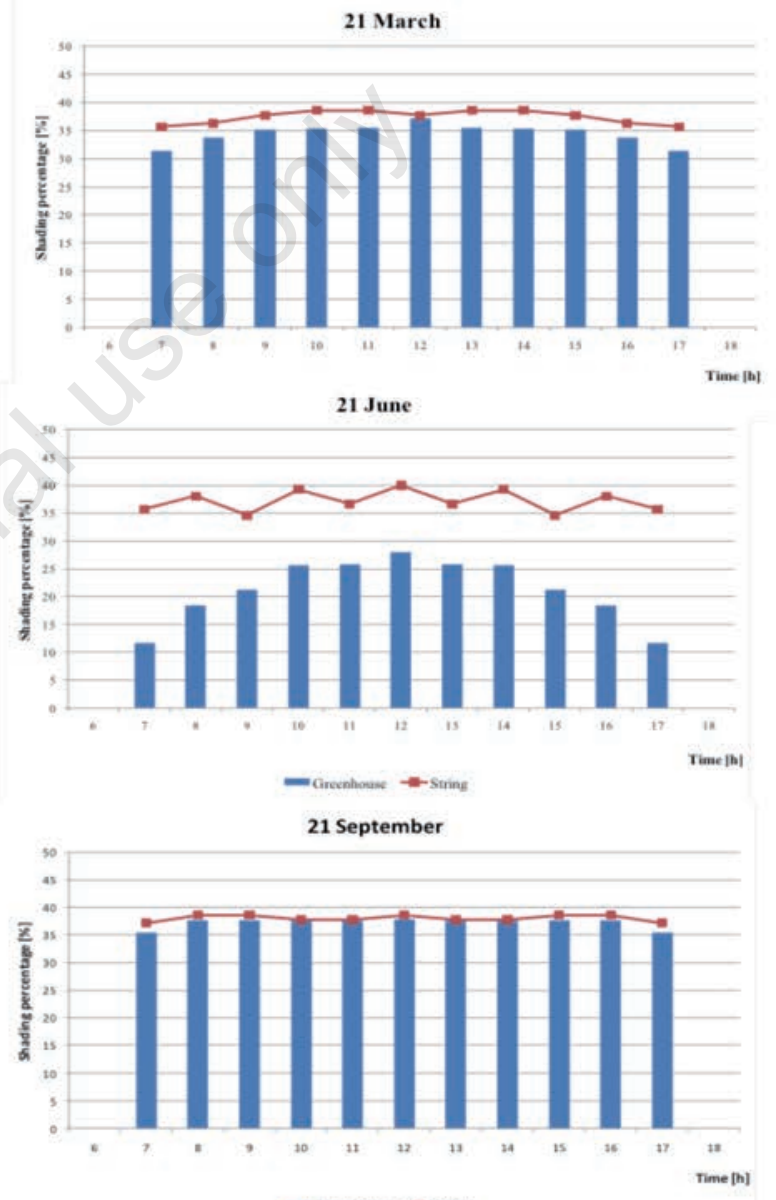

- Greenhouse - *-strine

21 December

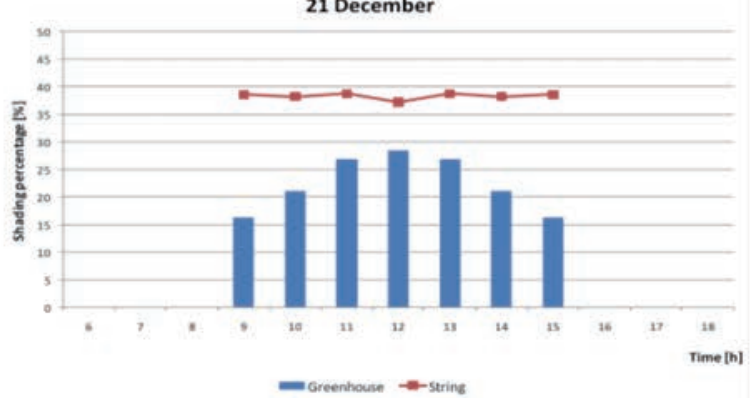

Figure 6. Shading percentage throughout the year. 
a parabola with downward concavity. These trends occur because in the first case (equinoxes), the shading is distributed evenly over the entire surface of the greenhouse, while in the second case (solstices) the shading is concentrated in the central part of the greenhouse, whereas the surface is not shaded in the vicinity of the longitudinal walls, with a consequent decrease in the mean shading.

Due to the factors described above, the percentage of shading with reference to the entire greenhouse surface tends to coincide with the percentage shaded by the PV panels under the string during equinox but tends to decrease significantly in the vicinity of the solstice.

Near the equinoxes, shading is distributed over the entire surface of the greenhouse, with positive effects on the shading uniformity over the crop. Near the solstices, instead, the shadow of the PV panels is concentrated in the north of the area covered, inevitably reducing the uniformity of the irradiation of the crops.

The shading percentage at 12:00, considering the entire surface of the greenhouse, varies between $27.8 \%$ (November) and $37.9 \%$ (September), thus changing by 10 percentage points.

Considering, however, only the shaded part of the photovoltaic string, the percentage of shading, again at 12:00, varies between $35.2 \%$ (November) and $40.6 \%$ (May), thus showing a variation interval half the size of the previous data.

The Figure 6 shows the values of the shading percentage inside the greenhouse with reference to the entire surface of greenhouse and the area corresponding to the width of a single photovoltaic string during all months of the year. In all months of the year, the percentage of shading never exceeds $40 \%$.

This value, similar to all other shading percentages, is related to the distance between the PV panels, which has been chosen; the value can be increased by reducing the distance between the PV panels.

In the first case, the trend shows the highest values at the equinoxes and solstices for the minor effect of the inner surfaces of the no-shaded greenhouse. More interestingly, for the agronomic evaluation of the system, is the trend of the percentage of shading under the string (PV panels projection), which appears constant throughout the year and for the duration of the day. This result is due to the curvature of the roof of the greenhouse tunnels and the east-west orientation of the structure.

A constant trend of shading on crops makes it possible to choose the behaviour throughout the year but above all makes it possible, by preparing a simple handling of the PV panels system, to remove the PV panels from the cover when the solar radiation decreases below a certain threshold as a result of cloudiness or the time of year.

A final issue addressed in this research is that both the constant value of shading on crops and the intensity (shading value) are important in analysing how the shading is distributed on crops.

Table 1 shows the size of the shadows inside the tunnel section at 12:00 on the twenty-first day of every month of the year.

Only in four months of the year (May, June, July and August) is the shadow of all PV panels completely inside the greenhouse section. In these months, the size of the shadow along the section is between $0.10 \mathrm{~m}$ to $0.15 \mathrm{~m}$. In other months, a substantial portion of shading due to the PV panels is outside the greenhouse, and the size of the section reaches values of $0.31 \mathrm{~m}$, more than in the four months mentioned above.

In general, the performance of various shades during the year varies with the angle of elevation of the sun. In the colder months (January, February, October, November and December), the size of the shadows along the section is much higher than in the hot months, and this reduction increases the uniformity of shading.

The variation of the size of the shadow depends on the angle of height of the solar rays and the tilt angle assumed by the PV panels due to the curvilinear shape of the section.

Table 1. Width of the shadows inside the tunnel section at 12:00 of the twenty-first day of every month of the year.

\begin{tabular}{|c|c|c|c|c|c|c|c|c|c|c|c|c|}
\hline $\begin{array}{l}\text { PV } \\
\text { panel }\end{array}$ & $\begin{array}{c}\text { January } \\
\text { (m) }\end{array}$ & $\begin{array}{l}\text { February } \\
\text { (m) }\end{array}$ & $\begin{array}{c}\text { March } \\
\text { (m) }\end{array}$ & $\begin{array}{c}\text { April } \\
\text { (m) }\end{array}$ & $\begin{array}{l}\text { May } \\
\text { (II) }\end{array}$ & $\begin{array}{l}\text { June } \\
\text { (m) }\end{array}$ & $\begin{array}{l}\text { July } \\
\text { (m) }\end{array}$ & $\begin{array}{l}\text { August } \\
\text { (m) }\end{array}$ & $\begin{array}{l}\text { September } \\
\text { (m) }\end{array}$ & $\begin{array}{l}\text { October } \\
\text { (m) }\end{array}$ & $\begin{array}{c}\text { November } \\
\text { (m) }\end{array}$ & $\begin{array}{c}\text { December } \\
\text { (m) }\end{array}$ \\
\hline 1 & 0.27 & 0.21 & 0.16 & 0.13 & 0.11 & 0.10 & 0.11 & 0.13 & 0.16 & 0.21 & 0.27 & 0.31 \\
\hline 2 & 0.27 & 0.21 & 0.17 & 0.13 & 0.11 & 0.11 & 0.11 & 0.13 & 0.17 & 0.21 & 0.27 & 0.30 \\
\hline 3 & 0.27 & 0.21 & 0.17 & 0.14 & 0.12 & 0.11 & 0.12 & 0.14 & 0.17 & 0.21 & 0.27 & 0.30 \\
\hline 4 & 0.26 & 0.21 & 0.17 & 0.14 & 0.12 & 0.12 & 0.12 & 0.14 & 0.17 & 0.21 & 0.26 & 0.29 \\
\hline 5 & 0.25 & 0.21 & 0.17 & 0.14 & 0.13 & 0.12 & 0.13 & 0.14 & 0.17 & 0.21 & 0.26 & 0.28 \\
\hline 6 & 0.25 & 0.20 & 0.17 & 0.15 & 0.13 & 0.13 & 0.13 & 0.14 & 0.17 & 0.21 & 0.25 & 0.27 \\
\hline 7 & 0.24 & 0.20 & 0.17 & 0.15 & 0.13 & 0.13 & 0.13 & 0.14 & 0.17 & 0.20 & 0.24 & 0.26 \\
\hline 8 & 0.23 & 0.19 & 0.17 & 0.14 & 0.13 & 0.13 & 0.13 & 0.15 & 0.17 & 0.19 & 0.23 & - \\
\hline 9 & 0.21 & 0.18 & 0.16 & 0.14 & 0.14 & 0.13 & 0.14 & 0.15 & 0.16 & 0.18 & 0.15 & - \\
\hline 10 & - & 0.17 & 0.16 & 0.14 & 0.14 & 0.13 & 0.14 & 0.14 & 0.16 & 0.17 & - & - \\
\hline 11 & - & 0.16 & 0.15 & 0.14 & 0.13 & 0.13 & 0.13 & 0.14 & 0.15 & 0.17 & - & - \\
\hline 12 & - & 0.15 & 0.14 & 0.13 & 0.13 & 0.13 & 0.13 & 0.14 & 0.14 & 0.15 & - & - \\
\hline 13 & - & 0.11 & 0.13 & 0.12 & 0.13 & 0.13 & 0.13 & 0.13 & 0.13 & 0.03 & - & - \\
\hline 14 & - & - & 0.13 & 0.12 & 0.13 & 0.13 & 0.13 & 0.13 & 0.12 & - & - & - \\
\hline 15 & - & - & 0.12 & 0.11 & 0.12 & 0.12 & 0.12 & 0.12 & 0.11 & - & - & - \\
\hline 16 & - & - & 0.11 & 0.11 & 0.12 & 0.12 & 0.12 & 0.11 & 0.10 & - & - & - \\
\hline 17 & - & - & 0.10 & 0.10 & 0.11 & 0.11 & 0.11 & 0.11 & - & - & - & - \\
\hline 18 & - & - & - & 0.09 & 0.11 & 0.11 & 0.11 & 0.10 & - & - & - & - \\
\hline 19 & - & - & - & - & 0.10 & 0.10 & 0.10 & 0.09 & - & - & - & - \\
\hline
\end{tabular}

PV, photovoltaic. 


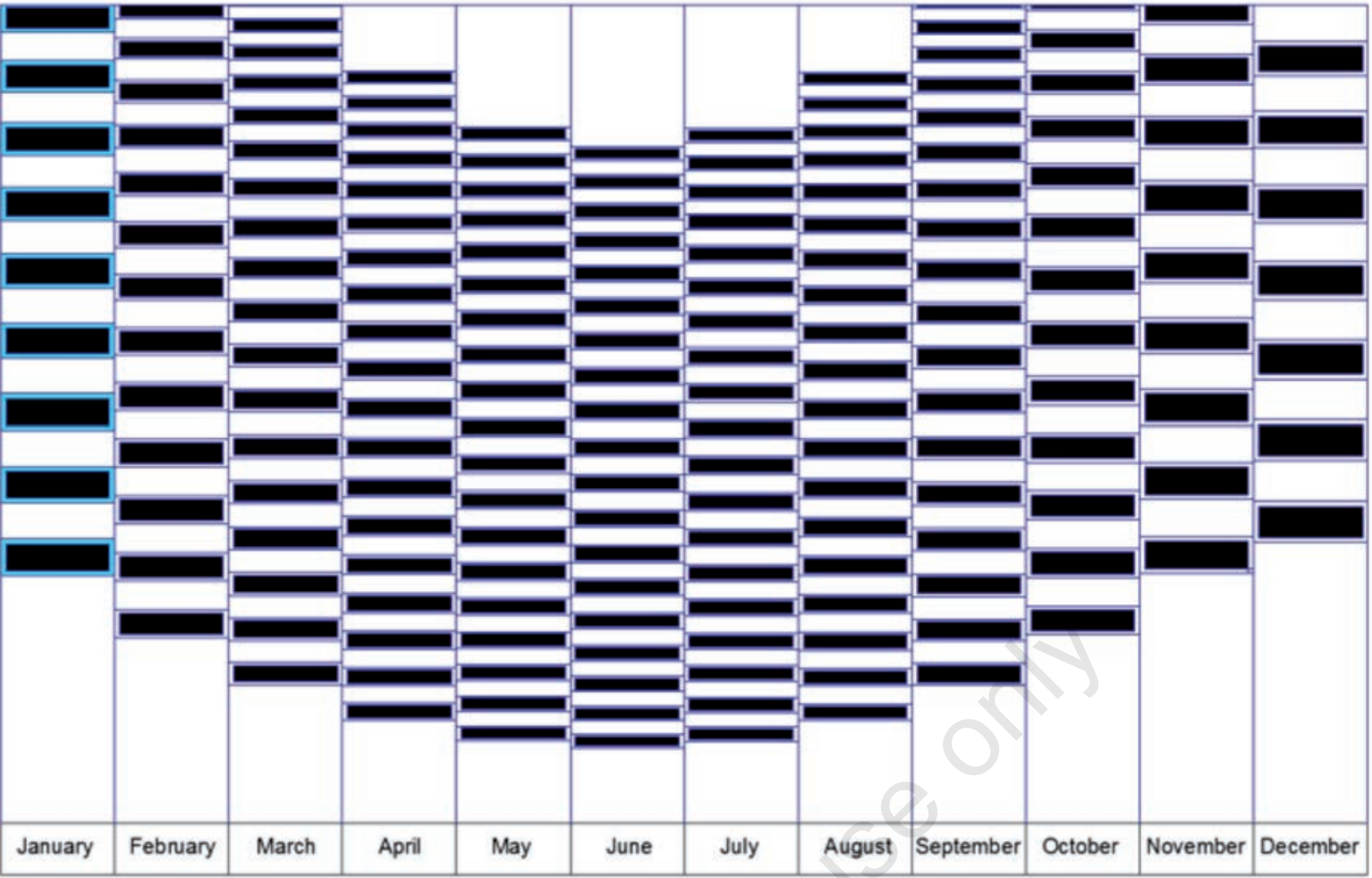

Figure 7. Distribution of the shadows on the $21^{\text {st }}$ day of each month of the year for the section.

To highlight the variation in the uniformity of shading during the year, the Figure 7 shows the distribution of the shadows on the $21^{\text {st }}$ day of each month of the year, considering both the whole of the greenhouse section and a single string of PV panels.

This figure shows that if the percentage of shading in the string is maintained almost constant throughout the year, the uniformity of the shading is much higher than during the summer period, which can only be a positive factor for crops grown in the protected environment.

\section{Conclusions}

This research concerns the shading distribution of the photovoltaic roof of a tunnel greenhouse. The cover was made using semi-transparent PV panels of $1.116 \times 0.165 \mathrm{~m}$.

With the arrangement of the PV panels adopted, from midMarch to mid-September, the shading in the middle of the day remains almost entirely inside the greenhouse. During the other months of the year, it is partly inside and partly outside the tunnel greenhouse.

The shading percentage of the PV panels under the string remains constant throughout the day, while the percentage of the entire surface of the greenhouse is constant in the vicinity of the equinox, while during the solstice, the trend of the shading percentage becomes a parabola with downward concavity.

With the photovoltaic cover adopted throughout the year, the shading percentage is never more than $40 \%$.

The shading by PV panels influence directly the solar radiation that reaches the plants, then it is important to evaluate the effect on crops of the trend of the shading percentages under the string, which is constant for the duration of the day and for every day of the year.

The constant trend of shading on crops makes it possible to choose the succession of the crops but also, with simple handling of the PV panels of the system, to remove them from cover when the solar radiation falls below a certain threshold due to cloudiness or the time of year.

A final issue addressed in the research concerns the uniformity of shading. In the colder months, the shading uniformity on crops is significantly increased, which depends on both the height of the sun and the angle of the PV panels, which varies along the tunnel section.

For to compare the trend of shading in the different conditions with the same greenhouse without shading is sufficient just do not consider the PV panels ( $0 \%$ shading by the PV panels).

\section{References}

Abdel-Mawgoud A.M.R., El-Abd S.O., Singer S.M., Abou-Hadid A.F., Hsiao T.C. 1996. Effect of shade on the growth and yield of tomato plants. Acta Hort. 434:313-20.

Al-Helal I.M., Al-Musalam I. 2003. Influence of shading on the performance of a greenhouse evaporative cooling system. J. Arab Gulf Sci. Res. 21:71-8.

Al-Shamiry F.M.S., Ahmad D., Sharif A.R.M., Aris I., Janius R., Kamaruddin R. 2007. Design and development of a photovoltaic power system for tropical greenhouse cooling. Am. J. Appl. Sci. 4:386-9. 
Castellano S., Santamaria P., Serio F. 2016. Solar radiation distribution inside a monospan greenhouse with the roof entirely covered by photovoltaic panels. J. Agric. Eng. 47:1-6.

Cockshull K.E., Graves C.J., Cave C.R.J. 1992. The influence of shading on yield of glasshouse tomatoes. J. Hort. Sci. 67:11-24.

Cossu M., Murgia L., Ledda L., Deligios P.A., Sirigu A., Chessa F., Pazzona A. 2014. Solar radiation distribution inside a greenhouse with south oriented photovoltaic roofs and effects on crop productivity. Appl. Ener. 133:89-100.

Dupraz C., Marrou H., Talbot G., Dufour L., Nogier A., Ferard Y. 2011. Combining solar photovoltaic panels and food crops for optimizing land use: towards new agrivoltaic schemes. Renew. Energy Generat. Appl. 36:2725-32.

Gent M.P.N. 2007. Effect of degree and duration of shade on quality of greenhouse tomato. Hortsci. 42:514-20.

Kadowaki M., Yano A., Ishizu F., Tanaka T., Noda S. 2012. Effects of greenhouse photovoltaic array shading on Welsh onion growth. Biosyst. Eng. 111:290-7.

Kittas C., Bailie A., Giaglaras P. 1999. Influence of covering material and shadingon the spectral distribution of light in greenhouses. J. Agric. Eng. Res. 73:341-51.

Lopez-Marin J., Galvez A., Gonzalez A., Egea-Gilabert C., Fernandez J.A. 2012. Effect of shade on yield, quality and photosynthesis-related parameters of sweet pepper plants. Acta Hortic. 956:545-52.

Lorenzo P., Guerro M.C.S., Medrano E., Garcia M.L., Caparros I., M. Giminez. 2003. External greenhouse mobile shading effect on microclimate water use efficiency and the yield of a tomato crop grown under different salinity levels of the nutrient solution. Acta Hort. 609:181-6.

Marucci A., Cappuccini A. 2016a. Dynamic photovoltaic greenhouse: Energy efficiency in clear sky conditions. Appl. Ener. 170: $362-76$.

Marucci A., Cappuccini A. 2016b. Dynamic photovoltaic greenhouse: Energy balance in completely clear sky condition during the hot period. Energy. 102:302-12.

Marucci A., Gusman A., Pagniello B., Cappuccini A. 2013a. Limits and prospects of photovoltaic covers in Mediterranean greenhouse. J. Agric. Eng. 44:1-8.

Marucci A., Monarca D., Cecchini M., Colantoni A., Allegrini E., Cappuccini A. 2013b. Use of Semi-transparent photovoltaic films as shadowing systems in Mediterranean greenhouses. ICCSA 2013, Part II, LNCS. 7972:231-41.

Marucci A, Monarca D, Cecchini M, Colantoni A, Manzo A, Cappuccini A. 2012. The semitransparent photovoltaic films for Mediterranean greenhouse: a new sustainable technology. Math. Probl. Engine. 2012:451934.

Marucci A., Monarca D., Cecchini M., Colantoni A., Cappuccini A. 2015. Analysis of internal shading degree to a prototype of dynamics photovoltaic greenhouse through simulation software. J. Agric. Eng. 46:144-50.

Sandra M.A., Andriolo J.L., Witter M., Ross T.D. 2003. Effect of shading on tomato plants grown under greenhouse. Hort. Brasil. 21:642-5.

Soni P., Salokhe1 V.M., Tantau H.J. 2005. Effect of screen mesh size on verticaltemperature distribution in naturally ventilated tropical greenhouses. J. Biosyst. Eng. 92:469-82.

Tudisca S., Di Trapani A.M., Sgroi F., Testa R., Squatrito R. 2013. Assessment of Italian energy policy through the study of a photovoltaic investment on greenhouse. Afr. J. Agric. Res. 8:3089-96.

Urena-Sanchez R., Callejon-Ferre A.J., Perez-Alonso J., CarrenoOrtega A. 2012. Greenhouse tomato production with electricity generation by roof-mounted flexible solar panels. Sci. Agric. 69:233-9.

Yano A., Furue A., Kadowaki M., Tanaka T., Hiraki E., Miyamoto M. 2009. Electrical energy generated by photovoltaic modules mounted inside the roof of a north- $\mathrm{S}$ oriented greenhouse. Biosyst. Eng. 103:228-38.

Yano A., Kadowaki M., Furue A., Tamaki N., Tanaka T., Hiraki E., Kato Y., Ishizu F., Noda S. 2010. Shading and electrical features of a photovoltaic array mounted inside the roof of an east-west oriented greenhouse. Biosyst. Engine. 106:367-77.

Yano A., Onoe M., Nakata J. 2014. Prototype semi-transparent photovoltaic modules for greenhouse roof applications. Biosyst. Engine. 122:62-73. 